\title{
Pesquisa sobre empresas juniores em instituições de ensino superior do Dis- trito Federal: estudo de caso com foco no Centro Universitário IESB
}

\author{
Matheus da Costa Medeiros \\ Graduado em Administração pelo Instituto de Educação Superior de Brasília. \\ E-mail: matcmedeiros@gmail.com (Brasil)
}

\section{Roberto Campos da Rocha Miranda}

Doutor em Ciências da Informação pela Universidade de Brasília (UnB). É professor do Instituto de Educação Superior de Brasília e Analista Legislativo da Câmara dos Deputados, atuando na Coordenação de Pós-Graduação como pesquisador. E-mail: rcrmiranda@gmail.com (Brasil)

\section{RESUMO}

Busca-se apresentar as características de empresas juniores instaladas em Instituições de Ensino Superior [IES], constituídas prioritariamente por discentes com o auxílio e gestão de docentes, para atender às necessidades do mercado e auxiliar no desenvolvimento da economia local e regional, capacitando os alunos e possibilitando experiências práticas, profissionais e oportunidades para obterem conhecimentos complementares fora das salas de aulas, bem como aumentar a visibilidade dos cursos das IES que aderirem ao modelo. Trata-se de pesquisa exploratória e bibliográfica, aplicada às IES localizadas no Distrito Federal, que possuem empresas juniores federadas ou qualquer outro modelo que se assemelhe. Foram realizadas entrevistas com os gestores das empresas juniores e aplicados questionários a uma amostra de alunos do curso de Administração de uma IES específica. Foram identificados, em documentos das empresas juniores, os erros mais comuns e as medidas frequentemente adotadas para corrigi-los ou evitá-los. Espera-se que as IES e os alunos que tenham a intenção de criar uma empresa universitária, possam utilizar os resultados auferidos no estudo para se orientarem, a fim de se obter melhores resultados no desempenho das empresas durante os seus primeiros anos de funcionamento.

Palavras-chave: Empresa júnior. Teoria-prática. Aprendizagem. Integração IES-empresa. Desenvolvimento profissional. 


\title{
Research about the junior companies in Brazilian Federal District higher education institutions: case study focused on University Center IESB
}

\begin{abstract}
The aim of this paper is to present the characteristics of junior companies from Higher Education Institutions (IES in Portuguese), constituted primarily by students with the help and management of teachers, to meet market needs and assist in the development of the local and regional economy, the students and enabling practical, professional experiences and opportunities to obtain complementary knowledge outside the classrooms, as well as to increase the visibility of the IES courses that adhere to the model. It is a qualitative-quantitative, exploratory and bibliographical research, applied to IES located in the Federal District, Brasília, Brazil, which have federated junior companies or any other model that resembles them. Interviews were conducted with the junior companies managers and questionnaires were applied to a sample of students from the Business and Management course of a specific IES. The most common mistakes and frequently adopted measures to correct or avoid them have been identified in youth business documents. It is expected that IES and students intending to set up a university junior company will be able to use the results of the study to orient themselves in order to obtain better results in the performance of companies during their first years of operation.
\end{abstract}

Keywords: Junior Company. Theory-Practice. Learning. IES-Company integration. Professional Development.

\section{Como referenciar em APA:}

Medeiros, M. C., \& Miranda, R. C. R. (2018). Pesquisa sobre empresas juniores em instituições de ensino superior do Distrito Federal: estudo de caso com foco no Centro Universitário IESB. R.G.Secr.,GESEC, 9(3).

\section{Como referenciar em ABNT:}

MEDEIROS, M. C.; MIRANDA, R. C. R. (2018). Pesquisa sobre empresas juniores em instituições de ensino superior do Distrito Federal: estudo de caso com foco no Centro Universitário IESB. R.G.Secr.,GESEC, v. 9, n. 3, Dez. 2018.
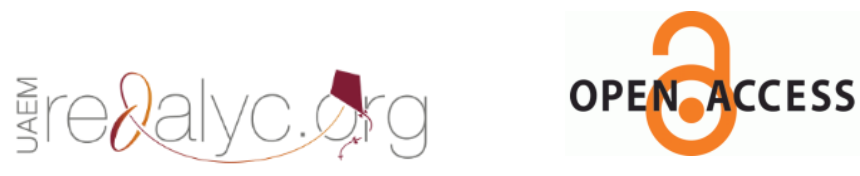


\section{Introdução}

As empresas juniores, doravante EJ, tornam-se um excelente complemento do conteúdo aprendido na sala de aula, onde o empresário júnior poderá contar com o apoio dos membros, ex-membros e com o quadro docente das Instituições de Ensino Superior - IES para auxílios e opiniões caso necessite para executar os projetos demandados. Porém, verifica-se diversidade na estruturação e constituição dessas EJ. Entretanto, muitas dessas empresas não conseguem ingressar no mercado, devido à inexperiência de gestão por parte dos membros.

Assim, este estudo tem como objetivo responder à questão: Qual o modelo mais adequado de empresa de consultoria e prestação de serviços formada por universitários em sua maioria, inserida em uma IES, para que possa atender as condições atuais do mercado? Nesse caso, traçaram-se como objetivos específicos do trabalho a) identificar possíveis fatores de sucesso das empresas juniores e de consultoria instaladas em IES no Distrito Federal; b) avaliar quais eram as intenções do Centro Universitário IESB ao abrir uma empresa de consultoria; e, c) verificar com alunos da graduação presencial fatores que consideram importantes para o seu aprendizado e motivadores na hora de participar de projetos oferecidos pela IES. Não estão incluídas neste estudo as incubadoras, por se tratarem de modalidades distintas, pois, diferentemente de uma EJ que procura atender clientes que queiram inserir-se no mercado, ou que já estejam instaladas, elas ajudam os empreendedores a desenvolver a sua ideia de empresa e as incubam por um determinado período, até que tenham condições necessárias para se inserirem no mercado.

O trabalho estrutura-se, primeiramente, com a apresentação do suporte teórico, trazendo o conceito, as condições, as características, os recursos, a estrutura e o funcionamento da EJ. Em um segundo momento, apresenta-se a metodologia empregada no estudo, com a indicação dos sujeitos de pesquisa (EJ do Distrito Federal), trazendo o foco para o desenvolvimento da EJ do IESB. Em seguida, são inseridas as análises e os resultados das entrevistas realizadas com gestores de EJ e os questionários aplicados aos alunos do curso de Administração do IESB. Finalmente, são indicadas recomendações para a criação de empresas de consultoria em IES, bem como as considerações finais. 


\section{Referencial Teórico}

\section{Conceito, condições e características de uma EJ}

Segundo a Confederação Brasileira de Empresas Juniores [Brasil Júnior], entidade representante do Movimento Empresa Júnior no Brasil [MEJ], são condições para que se configure uma EJ: a) formadas e geridas unicamente por alunos graduandos; b) são organizações sem fins econômicos e que as receitas obtidas devem ser reinvestidas na própria EJ; c) devem ser consideradas autônomas, respondendo por todos os seus atos; e d) estarem associadas a uma IES. Para tal, a EJ não deve sofrer qualquer intervenção externa na sua gestão, nem do corpo docente nem dos coordenadores dos cursos (Brasil Júnior, 2012).

Para que seja reconhecido oficialmente pela Brasil Júnior como uma EJ, as partes interessadas devem seguir os critérios estabelecidos em documento do Conceito Nacional de Empresa Júnior, conforme o excerto a seguir:

A verificação de todos os critérios estabelecidos pelo Conselho Nacional de Empresa Júnior, a fím de determinar se uma associação pode ou não ser considerada uma Empresa Júnior, será realizada pela Brasil Júnior e suas federações de empresas juniores confederadas, de acordo com as normas estabelecidas pela Brasil Júnior (Brasil Júnior, 2012, p. 3).

Como forma de padronizar e facilitar o funcionamento das EJ, a Brasil Júnior criou o Conceito Nacional de Empresa Júnior, documento responsável por deliberar alguns critérios para que uma empresa formada por alunos possa ser considerada uma EJ e reconhecida pelo mesmo (Brasil Júnior, 2012).

O Quadro 1 apresenta os aspectos relevantes considerados por EJ com as suas descrições e exemplos.

Quadro 1 - Critérios das EJ.

\begin{tabular}{|c|ll|}
\hline $\begin{array}{c}\text { Aspectos } \\
\text { Relevantes }\end{array}$ & \multicolumn{1}{c|}{ Descrição } \\
\hline & $\bullet \quad \begin{array}{l}\text { Disponibilizar aos integrantes a possibilidade de desenvolvimento profissional, por } \\
\text { meio dos projetos e serviços realizados, colocando em prática o conteúdo aprendido na } \\
\text { sala. }\end{array}$ \\
& $\begin{array}{l}\text { Buscar o desenvolvimento dos comércios regionais, prestando serviços para empresá- } \\
\text { rios e novos entrantes. }\end{array}$ \\
\hline
\end{tabular}




\begin{tabular}{|l|ll|}
\hline \multicolumn{1}{|c|}{$\begin{array}{c}\text { Aspectos } \\
\text { Relevantes }\end{array}$} & & \multicolumn{1}{c|}{ Descrição } \\
\hline $\begin{array}{l}\text { Quadro de } \\
\text { pessoas }\end{array}$ & $\bullet$ & $\begin{array}{l}\text { As EJ devem ser constituídas por alunos que estão matriculados na IES e que se en- } \\
\text { contram regulares no (s) curso(s) de graduação vinculado a EJ. }\end{array}$ \\
\hline $\begin{array}{l}\text { Fontes de } \\
\text { receitas e } \\
\text { remuneração }\end{array}$ & $\bullet$ & $\begin{array}{l}\text { As EJ devem ter como fonte de receitas as arrecadações provenientes dos serviços e } \\
\text { projetos realizados. }\end{array}$ \\
\hline $\begin{array}{l}\text { Seus membros devem ser voluntários, não podendo receber nenhuma forma de remu- } \\
\text { neração, exceto para cobrir custos de projetos. }\end{array}$ \\
Aspectos & $\bullet$ & $\begin{array}{l}\text { Ser registrada no CNPJ/MF. } \\
\text { Respeitar e observar as leis estabelecidas para o quadro de pessoa jurídica a qual esti- } \\
\text { legais }\end{array}$
\end{tabular}

Fonte: Adaptado de Brasil Júnior (2012).

\section{Recursos, estrutura e funcionamento das EJ}

Para poder planejar, estruturar, registrar e dar início as suas operações, as EJ também terão custos envolvidos nesses processos, cabendo aos membros encontrarem meios de captar recursos e reduzir os custos. Uma forma de conseguir esses meios é buscar o apoio da IES para ceder infraestrutura e auxílio com advogado e contador, já que serão as partes mais onerosas durante esse período. As EJ podem receber recursos financeiros diretos das IES desde que a IES não cobre uma porcentagem em cima dos ganhos, e nem entrem como sócia da EJ (Brasil Júnior, 2014). "Como a EJ é uma entidade sem fins econômicos, a renda deve ser redirecionada a dois pontos estratégicos: geração de aprendizado aos seus membros e, principalmente, reinvestimento interno" (Brasil Júnior, 2014, p. 15). Após a abertura e o funcionamento da EJ, espera-se que os serviços prestados aos seus clientes se tornem a principal fonte de receita e que possam cobrir os custos de operação e realizações de projetos. (Brasil Júnior, 2012, p. 30).

Segundo a Brasil Júnior (2014, p. 12), a maior dificuldade encontrada pelos alunos junto as IES para a criação de uma EJ é conseguir um espaço físico fixo para montarem as instalações, já que as IES não possuem a obrigação de ceder um local em seu campus, e nem as EJ de estarem presentes fisicamente no campus, havendo somente a necessidades de estarem vinculadas a IES. Historicamente, as IES particulares são mais receptíveis quanto à abertura de uma EJ, tornando as negociações entre os alunos e coordenadores mais fáceis. Outro fato importante é que as IES particulares têm percebido a importância de disponibilizar aos 
seus alunos experiências fora das salas de aulas, ou seja, experiências práticas (Brasil Júnior, 2014, p. 12). Em relação a mobílias, equipamentos e materiais, são dos membros, a responsabilidade de consegui-los. As IES podem doá-los à EJ, já que algumas, periodicamente realizam a renovação e atualização do campus, desde que não seja de caráter obrigatório, e esperase que futuramente as EJ os adquira com as próprias receitas (Brasil Júnior, 2014, p.13).

Com o intuito de guiar os novos empresários juniores e EJ do Brasil, a Brasil Júnior (2012) desenvolveu uma espécie de manual com os principais modelos de gestão e práticas mais vistas em EJ que estão em funcionamento e obtendo sucesso. Não sendo obrigatório seguir o modelo, caberá aos membros diretores, de acordo com a necessidade e condições da EJ, decidirem se será viável ou não segui-lo. No manual, denominado DNA Júnior, recomenda-se para a abertura de uma EJ, seis pessoas, para ocupar áreas consideradas importantes para a gestão, que são: presidência, administrativo-financeiro, marketing, $\mathrm{RH}$, projetos e qualidade. Os cargos de diretores são designados para os membros que tenham interesses nas áreas. A presidência é indicada, no primeiro momento para o desenvolvedor da ideia de abertura da EJ ou o membro com mais interesse. Durante o processo de abertura e os primeiros meses de funcionamento da EJ, é recomendável seguir esse quadro pessoal até ter condições para requisitar novos membros. (Brasil Júnior, 2012).

Serão esses primeiros membros quem vão decidir o futuro da EJ, ou seja, construir todos os próximos passos, como nome, objetivos, missão, visão, valores, negócio, serviços, produtos, clientes, mercado de atuação, processos, entre outros. Também serão eles os responsáveis por cuidar de toda a parte burocrática e jurídica para a legalização e poder iniciar as atividades da empresa.

\section{Importância da EJ para o aprendizado}

Com as novas tendências no mercado de trabalho, as IES precisam buscar novos meios de ensinar seus alunos, já que o tradicional método (aulas conceituais dentro da sala de aula) não tem mais a mesma eficiência de tempos anteriores. Os alunos têm buscado mais dinamismo nas aulas e fora delas, que os conteúdos venham de forma prática e rápida, já que conseguem os conceitos dos temas abordados na internet, vídeos aulas, sites, livros online, artigos científicos e outros trabalhos acadêmicos. A facilidade imposta pela Internet e a globalização permitem aos seres humanos ter acesso a informações primordiais e rápidas (apenas com um 
clique), fato que antes dos anos 1980 não era possível, ou o tempo para consegui-las não era viável (Peixoto, 1997).

Assim, a EJ propicia ambiente onde os participantes (empresários juniores) poderão aplicar, na prática, seus conhecimentos adquiridos nas salas de aula, já que trazem problemas e situações cotidianas na vida dos empresários e futuros bacharelados. Com os serviços que podem ser ofertados (consultorias, campanhas publicitárias, recrutamento, assessoria jurídica, entre outros) os integrantes das EJ são os responsáveis por oferecer uma solução para os empresários ou outros indivíduos que procurarem os serviços ofertados pelas EJ. Como a empresa se encontra dentro de uma IES, os empresários juniores poderão contar com o auxílio dos docentes e coordenadores, tornando-se assim, a EJ uma espécie de laboratório propiciador de melhores condições para o aprendizado (Souza, 2002).

A relação entre os estudantes e as EJ estabelece um padrão no qual eles percebem que há uma necessidade de obter conhecimentos a mais do que é ensinado nas salas de aulas. Os empresários juniores mostram uma atitude positiva com a EJ por saber o quanto a experiência lá adquirida poderá ser útil no futuro, tanto para quem pretende ser empreendedor (proprietário do seu próprio negócio) quanto os profissionais assalariados ou prestadores de serviços (Dias, Vilas Boas, Oliveira \& Moreira, 2010, p. 13).

Como as EJ estão instaladas em um ambiente acadêmico, os novos membros (empresários juniores) têm a possibilidade de solicitar ajuda aos docentes das IES e também contam com o apoio dos membros mais experientes que buscam compartilhar os conhecimentos adquiridos sem ter um clima tão competitivo como numa empresa de consultoria no mercado. Esse apoio tem-se mostrado primordial, já que os empresários juniores não possuem total conhecimento e experiências mais vastas na área a qual, normalmente, prestará os serviços e consultorias. Além da monitoria, os empresários juniores tendem a ter mais autonomia e próatividade para procurarem soluções individualmente ou com o grupo de participantes das EJ, deixando para último caso a solicitação de ajuda a membros não participantes do projeto e/ou docentes da IES. Ainda segundo o mesmo autor, a mentoria tem-se mostrado uma ferramenta eficaz e muito importante para o aprendizado nessas EJ, onde o contato com alguém mais experiente é repassado para os novos membros por meio de relacionamentos cotidianos no ambiente de trabalho, à medida que as situações/problemas vão surgindo, desenvolvendo assim o aprendizado na prática (Santos, Brito-de-Jesus, Souza-Silva, Silva \& Franco, 2013). 


\section{Vantagens e benefícios das EJ}

As EJ tendem a ter total apoio das IES por estarem inseridas em seu contexto. Tal apoio inclui, desde as instalações físicas, como também consultas aos docentes, tendo assim, condições de ofertarem serviços de qualidade com um baixo custo de produção. Para os integrantes das EJ, ela possui um papel fundamental de integrar os conceitos ensinados nas faculdades com a prática necessária no mercado de trabalho. Em contrapartida, as EJ poderão gerar retornos para as IES, divulgando a sua marca para o mercado, podendo atrair novos parceiros comerciais e ser responsável na escolha da IES pelos futuros universitários (Santos et al., 2013; Santos, R., 2012).

Pensando-se em disseminar o conceito de empresa júnior entre as universidades brasileiras, a Brasil Júnior interveio junto ao governo e propôs uma mudança estrutural nos critérios de avaliação das IES. A partir de então, as IES que adotarem uma empresa júnior na sua estrutura serão mais bem cotadas na pesquisa que elege as melhores universidades (Brasil Júnior, 2014, p. 13).

O auxílio das IES para os empresários juniores é um diferencial para o aprendizado dos participantes em relação a experiências que eles encontrariam em uma empresa convencional, por exemplo. Esse estreitamento no relacionamento IES e empresários juniores possibilitam condições para o desenvolvimento acadêmico e profissionais, já que disponibiliza ferramentas e condições favoráveis (Santos, R., 2012). O estudante de nível superior, quando consegue estágio na área escolhida de graduação, tende a sentir-se mais realizado e satisfeito com a sua opção de bacharelado. O estágio é uma ferramenta que se tem mostrado eficaz na sua aplicação, fazendo com que esses estudantes tenham uma direção para qual área atuar no futuro, desenvolvendo assim a sua futura carreira. O indivíduo satisfeito com a sua escolha profissional tende a se tornar mais aberto e atento às oportunidades que virão surgir no mercado (Silva et al. 2013). Já para os empreendedores interessados em serviços de consultoria e que tenham baixas receitas, possuem, por meio da EJ, a oportunidade de ter acesso a esses serviços, já que os preços praticados pelas EJ são, historicamente, menores do que os praticados pelas empresas de consultorias tradicionais do mercado (Brasil Júnior, 2012). 


\section{Metodologia}

A pesquisa possui caráter exploratório e bibliográfico foi desenvolvida com todas as 22 EJ do Distrito Federal, federadas pela Concentro (2015) e certificadas até o início de 2015 com o Selo EJ. São elas:

a) AD\&M: EJ criada em 1993, formada por alunos da UnB - Universidade de Brasília. Os seus principais serviços são soluções nas áreas de finanças, GP, marketing e organização e processos;

b) CJR: EJ criada em 1999, é uma empresa formada por alunos de ciências da computação e computação licenciatura da UnB. O seu principal objetivo é formar pessoas transformadoras capazes de impactar a história dos seus clientes. Os seus principais serviços são: desenvolvimento de páginas de internet, sistemas, consultorias e treinamentos;

c) Concreta: EJ formada por alunos dos cursos de engenharia civil, ambiental e arquitetura e urbanismo da UNB. Foi fundada em 1996. Os seus principais serviços são: projeto de arquitetura, interiores, estrutural, fundações, instalações elétricas e de telefones, instalações hidrossanitárias, consultorias em patologias de construção e quantitativo de materiais;

d) Conex: EJ formada por alunos de Relações Internacionais da Universidade Católica de Brasília - UCB. Foi fundada em 2001. Seus principais serviços são: consultoria de exportação e importação, planejamento e estruturação das futuras operações de importação da empresa; consultoria governamental, plano de marketing, análise de mercado e a concorrência, consultoria para pessoa física, capacitando o empresário para as negociações, e cursos;

e) Dois novemeia: EJ fundada em 1996 por alunos de comunicação da UnB. Seus principais serviços são publicidades em geral, como: malas diretas, e-mails, marketing, ações de marketing. Fôlderes, spot, cartaz, convites;

f) Domani: EJ formada por alunos da UNB e que oferecem serviços de análise de conjuntura internacional, planejamento de exportação e importação, prospecção de feiras setoriais internacionais e assessoria em negociações internacionais;

g) Ecoflor: EJ fundada em 2008 por alunos de engenharia florestal da UnB. Seus principais serviços são: arborização e paisagismo, estudos ambientais, gerenciamento de áreas silvestres, neutralização de carbono, planejamento e administração de plantios florestais; 
h) Econsult: EJ de economia da UnB, fundada em 2001. Seus principais serviços são: projeto de financiamento, otimização de preço e venda, viabilidade econômica-financeira, estudo de mercado, reestruturação financeira, assessoria econômica, valuation;

i) Embragea: EJ de gestão ambiental da UnB, fundada em 2011. Seus principais serviços são: compensação de carbono, educação ambiental, plano de gerenciamento de resíduos sólidos e sistema de gestão ambiental;

j) Enetec: EJ de engenharia elétrica da UnB, fundada em 2006. Seus principais serviços são: instalações elétricas, fontes renováveis de energia, eficiência energética;

k) Engnet: EJ de consultoria e implementação de sites e sistemas da UnB;

1) Estat: EJ de estatística da UnB, fundada em 1995. Os seus principais serviços são: Análise descritiva e multivalorada, digitação de questionários, planejamento amostral e de pesquisa, regressão linear simples, revisão de banco de dados e testes não paramétricos;

m) Facto: EJ de jornalismo da UnB, fundada em 2009. Seus principais serviços são: plano de comunicação integrada, planejamento editorial, cobertura de eventos, gerenciamento e produção de conteúdo, assessoria de imprensa;

n) Grupo Gestão: EJ de engenharia de produção da UnB. Seus principais serviços são: ergonomia e segurança no trabalho, gestão da qualidade, gestão estratégica e organizacional, gestão do produto, gestão empresarial e gestão da produção;

o) Lamparina Design: EJ de desenho industrial da UnB. Seus principais serviços são: identidade visual, material promocional, design editorial, design de interfaces, layout de sites, sinalização e ambientação, design tipográfico, ilustração, desenho técnico, conceituação de produtos, embalagem e design de moda;

p) Mecajun: EJ de engenharia mecatrônica da UnB. Fundada em 2001. Seus principais serviços são: projetos em controle e automação, análise de produtividade e custos, cursos de capacitação tecnológica;

q) Nutrir: EJ de ciências da saúde, nutrição da UnB. Seus principais serviços são: avaliação e orientação nutricional, atividades educativas de saúde e nutrição, coffee-break saudável, planejamento de cardápio, manual de boas práticas de fabricação, rotulagem nutricional, ficha técnica de preparação;

r) Praxis: EJ de psicologia da UnB. Seus principais serviços são: ergonomia, psicologia do consumidor e qualidade de vida no trabalho, orientação profissional de grupo e institucional, planejamento de carreira, análise e diagnóstico organizacional, avaliação de desempe- 
nho, plano de cargos e salários, clima organizacional, recrutamento, seleção, treinamento, planejamento instrucional;

s) Projetos consultoria integrada: EJ do Centro Universitário UniCEUB. Oferece consultoria às organizações nas áreas de conhecimento dos cursos de graduação da própria instituição;

t) Pupila: EJ da Universidade de Brasília na área de atuação audiovisual. Fundada em 2008. Seus principais serviços são: vídeos institucionais, promocionais, spot de rádio, videoclipes e animações;

u) Strategos: EJ de ciência política e gestão de políticas públicas da UnB. Seus principais serviços são: agenda legislativa, monitoramento do poder executivo e do legislativo, pesquisa de opinião eleitoral e parlamentar, fortalecimento institucional;

v) Tecmec: EJ de engenharia mecânica da UnB. Fundada em 2004. Seus principais serviços são: metrologia, ar condicionado e refrigeração, motores de combustão interna, sistemas mecânicos, processos de fabricação e soldagem, integridade estrutural, sistemas alternativos de geração de energia, textos de patente, desenho técnico.

Considerando a necessidade de se estabelecer foco no estudo e em função da dificuldade de acesso aos reitores de outras IES, optou-se por se analisar o que motivou o Centro Universitário IESB a investir em um projeto como a L2M (2014), estudo de caso relatado neste artigo. Assim, realizou-se uma entrevista com a reitora da instituição e, complementarmente, foi realizado levantamento com os alunos da graduação em Administração do Centro Universitário IESB campus norte, localizado na quadra 609, Asa Norte, Distrito Federal. A escolha do curso de administração se deu em virtude do olhar para organizações sem fins lucrativos, voltadas para consultoria, dentro de IES, tema que é objeto da formação de alunos da área de administração.

As informações foram recolhidas por meio da entrevista estruturada, ou seja, com um roteiro elaborado, e realizadas pessoalmente. Como as EJ possuem vários procedimentos semelhantes, algumas respostas dadas pelos entrevistados passaram a ser redundantes, sendo que se utilizou a amostra por saturação para tratar de determinados temas, como, por exemplo, processo de gestão. Dessa forma, além do Centro Universitário IESB, foram entrevistados representantes de EJ do UniCEUB, da UCB e da UnB. As entrevistas tiveram uma duração média de 40 minutos e as informações dadas pelos entrevistados foram digitadas no computador, separando um arquivo para cada EJ entrevistada, e para os entrevistados que autorizaram 
a gravação foi utilizado um aparelho celular, ajudando a preservar todos os conteúdos expostos por eles.

As variáveis foram baseadas no referencial teórico e comparadas com as levantadas nas entrevistas e no questionário aplicado, estabelecendo assim, um alinhamento de interesses entre o modelo proposto, alunos e IES. Os principais fatores levados em consideração nas entrevistas com as EJ foram: relação da empresa com a IES, relação com os estudantes e membros da empresa, estrutura organizacional, fontes de receitas e utilização, relações públicas da empresa. Na entrevista com a reitora do Centro Universitário IESB foram questionados: se conhece o MEJ, como surgiu a ideia de abrir uma empresa no formato da L2M, quais eram os objetivos esperados pelo IESB em relação a L2M e o que ocorreu com o projeto. Foram aplicados 108 questionários aos alunos do curso de Administração do Centro Universitário IESB, que se interessaram em participar da pesquisa, e houve preocupação em avaliar as variáveis relacionadas a análises demográficas, metodologias que consideram importantes para a aprendizagem durante o curso de graduação e fatores que os motivariam a participar de projetos oferecidos pela IES.

\section{Análises}

A análise foi dividida em três partes de acordo com os objetivos específicos, sendo elas: entrevista com empresas juniores, entrevista com a reitoria e por fim, o questionário com os alunos.

\section{Entrevistas com gestores de empresas juniores}

Como as EJ possuem alguns processos semelhantes, já que se baseiam no Conceito Nacional de Empresa Júnior [CNEJ], os levantamentos de dados das entrevistas enfatizaram as EJ que se sobressaem em relação às outras em um determinado processo, e em outros momentos, as que estão abaixo da média.

\section{Relação das EJ com a IES}

Para melhor ilustrar o resultado das respostas do relacionamento entre EJ e IES, foi de desenvolvido o quadro 2 de envolvimento IES e EJ. 
Quadro 2- Envolvimento entre IES e EJ.

\begin{tabular}{|c|c|c|c|}
\hline Quesito & UniCEUB & UCB & UnB \\
\hline Recursos & $\begin{array}{l}\text { A Projetos tem total } \\
\text { apoio em relação à } \\
\text { estrutura física e } \\
\text { elétrica, equipamen- } \\
\text { tos eletrônicos e } \\
\text { alguns materiais de } \\
\text { escritório; não rece- } \\
\text { bem e nem repassam } \\
\text { recursos financeiros } \\
\text { para a IES. }\end{array}$ & $\begin{array}{l}\text { A UCB disponibili- } \\
\text { zou equipamentos } \\
\text { eletrônicos, mesas e } \\
\text { cadeiras e toda a } \\
\text { infraestrutura para a } \\
\text { EJ. Não recebem e } \\
\text { nem repassam recur- } \\
\text { sos financeiros para a } \\
\text { IES. }\end{array}$ & $\begin{array}{l}\text { A UnB cedeu todos os espaços físicos das EJ; } \\
\text { A distribuição dos recursos por parte da UnB } \\
\text { fica a critério do departamento de cada curso, } \\
\text { não podendo repassar nenhum recurso finan- } \\
\text { ceiro, mas ajudando-os em reformas e ceden- } \\
\text { do materiais e equipamentos eletrônicos. Há } \\
\text { casos de EJ que necessitam somente do espa- } \\
\text { ço físico, como a Estrategos que no início dos } \\
\text { seus processos precisaram de doações por } \\
\text { parte da IES, mas atualmente os seus equipa- } \\
\text { mentos e materiais são adquiridos com os } \\
\text { próprios recursos provenientes da execução } \\
\text { dos seus projetos. }\end{array}$ \\
\hline $\begin{array}{l}\text { Intervenção } \\
\text { dos proces- } \\
\text { sos adminis- } \\
\text { trativos }\end{array}$ & $\begin{array}{l}\text { A tomada de decisão } \\
\text { é de total autonomia } \\
\text { da EJ, porém o Uni- } \\
\text { CEUB sempre acom- } \\
\text { panha os projetos } \\
\text { externos. }\end{array}$ & $\begin{array}{l}\text { Não há nenhuma } \\
\text { intervenção por parte } \\
\text { da IES em relação a } \\
\text { tomadas de decisões } \\
\text { da EJ. }\end{array}$ & $\begin{array}{l}\text { A UnB não intervém em nenhuma das EJ, mas } \\
\text { como o Centro de Apoio ao Desenvolvimento } \\
\text { Tecnológico - CDT/UnB oferece créditos de } \\
\text { extensão para os participantes das EJ, eles } \\
\text { exigem um relatório de frequência dos mem- } \\
\text { bros e que a EJ escolha um professor orienta- } \\
\text { dor. A Econsult possui um conselho consulti- } \\
\text { vo formado por professores e ex-membros das } \\
\text { EJ para auxiliá-los nas tomadas de decisões, } \\
\text { que consideram a experiências dessas pessoas } \\
\text { como sendo fundamentais para o sucesso da } \\
\text { empresa. }\end{array}$ \\
\hline $\begin{array}{l}\text { Auxílios e } \\
\text { benefícios }\end{array}$ & $\begin{array}{l}\text { A IES oferece profes- } \\
\text { sores orientadores; } \\
\text { ajuda na divulgação } \\
\text { da EJ para os alunos } \\
\text { da instituição de } \\
\text { ensino; libera espaços } \\
\text { em eventos dos quais } \\
\text { o UniCEUB participa } \\
\text { para que a EJ divul- } \\
\text { gue a sua marca }\end{array}$ & $\begin{array}{l}\text { Oferecem professores } \\
\text { orientadores; ajudam } \\
\text { na divulgação da EJ } \\
\text { no site e redes sociais } \\
\text { da UCB. }\end{array}$ & $\begin{array}{l}\text { Espaço para montar stand em alguns eventos } \\
\text { realizados pelo CDT; créditos de extensão } \\
\text { para os membros; professores orientadores; } \\
\text { ajuda na divulgação. }\end{array}$ \\
\hline
\end{tabular}

Fonte: Elaboração própria.

\section{Relação das EJ com estudantes e membros}

A maior parte das EJ da UnB informou que não possuem muitas ações voltadas para os alunos, sendo, em sua maioria, aulas inaugurais durante o início de semestre para os alunos calouros, nas quais os professores cedem o espaço para a EJ apresentar a empresa e o período de processo seletivo. Há EJ que tentam ampliar o relacionamento com os alunos como a Ecoflor, que realiza promoções nas suas redes sociais tentando interagir a empresa com o público que a acompanha. Já a Estrategos faz uma aproximação por meio de eventos: criaram a "Stra- 
tegos Apresenta", uma iniciativa aberta para o público em geral, trazendo palestras e realizando workshops.

A Projetos faz a aproximação com os alunos por redes sociais, diretórios acadêmicos da universidade, bem como cursos na EJ para os seus membros. Quando há vagas, abrem para alunos da IES.

$\mathrm{Na}$ Conex, a aproximação é feita por cursos semestrais que a EJ oferece aos alunos da UCB, principalmente aos de relações internacionais, curso no qual recrutam seus membros.

Já em relação aos membros, as EJ da UnB e UCB, só contratam discentes do curso ao qual a EJ está relacionada: por exemplo, a Nutrir com o curso de nutrição e a Engnet com o curso de engenharia de redes.

As EJ têm a difícil missão de manter os seus colaboradores por mais tempo na empresa, já que o salário vai contra os princípios do MEJ e não possuem nenhum tipo de vínculo empregatício, sendo o trabalho prestado voluntariamente. O período médio de rotatividade dos membros de todas as EJ entrevistadas está em torno de 1 ano e 3 meses, variando entre empresas onde os membros permanecem em média seis meses como no caso da Embragea a um ano e seis meses na AD\&M.

Para tentar diminuir a rotatividade dos membros, as EJ oferecem meios para a capacitação profissional e pessoal sendo em sua maioria projetos externos e cursos. Outras, percebendo que somente a experiência profissional não estava sendo suficiente, começaram a desenvolver políticas de benefícios, como na Estat, na qual criaram uma espécie de moeda própria para beneficiar os membros que participaram dos projetos externos, pagando uma porcentagem sobre projeto. Quando solicitado, o membro pode pedir a troca da moeda em livros, participação de eventos e realização de cursos. A Projetos conseguiu junto ao UniCEUB uma bolsa para os diretores e presidentes da EJ, e outro exemplo é a Praxis que foca no endomarketing da empresa, com políticas de alinhamento, integração e acompanhamentos individuais.

\section{Estrutura organizacional}

O organograma das EJ estudadas são muitos parecidos onde é composto por um presidente institucional (responsável pelo relacionamento externo da EJ), um presidente organizacional (responsável pelo relacionamento interno da EJ), diretorias e por fim, os membros. $\mathrm{O}$ que varia entre algumas EJ são a adição de conselho ou assembleias, como exemplo, a Econ- 
sult que acima dos presidentes tem a assembleia geral e abaixo tem o conselho consultivo, formado por ex-membros e professores. As áreas das empresas diferenciam-se em relação aos produtos e serviços que oferecem, mas sempre existem as áreas de administrativo-financeiro e gestão de pessoas. Um exemplo da exceção é o organograma da Praxis, representado pela Figura 2, em que a assembleia geral (reunião de todos os membros) é o nível hierárquico mais alto seguido pelo conselho diretor (reunião das diretorias) e a presidência fica representada pela diretoria-presidência, no mesmo nível hierárquico das outras diretorias.

Figura 1 - Organograma da Praxis.

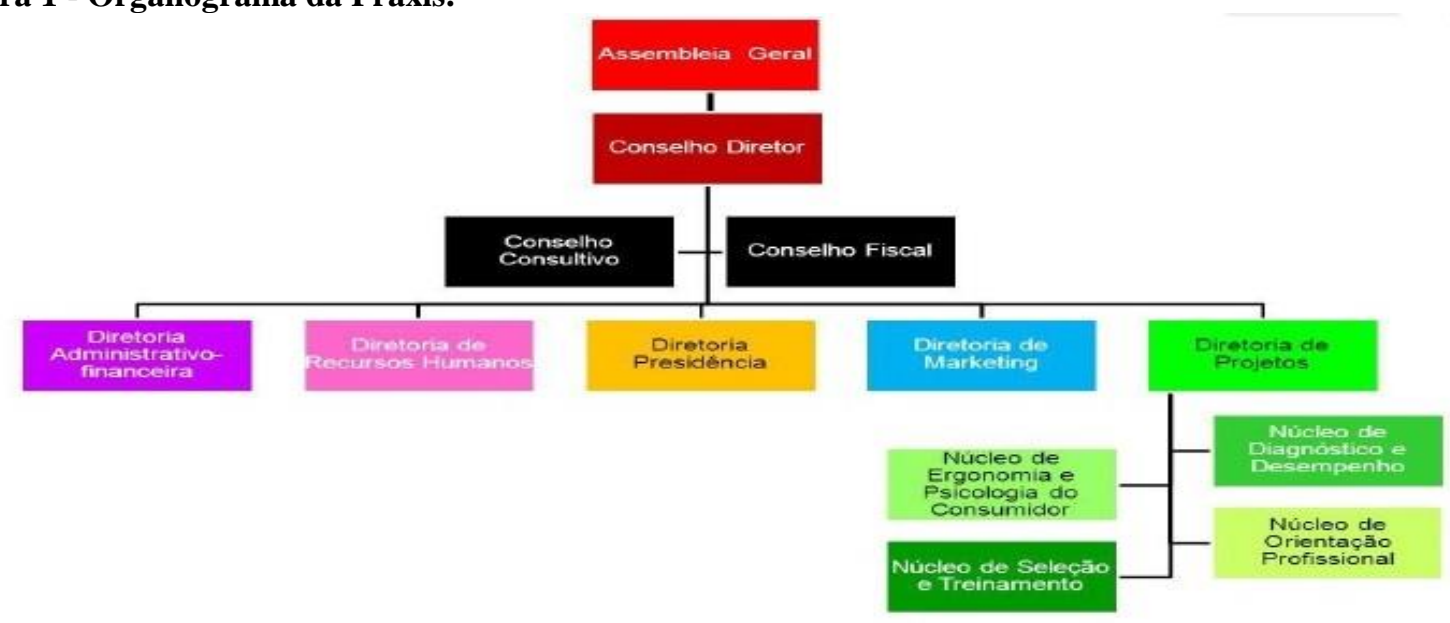

Fonte: Praxis.

\section{Fontes de receitas e utilização}

Verifica-se que todas as EJ estudadas obedecem ao princípio de não terem fins lucrativos e nem receberem recursos financeiros, sendo que a principal fonte de receita é proveniente dos projetos de consultorias externos.

Quanto às receitas obtidas pelas EJ, estas são revertidas para cobrir suas obrigações fiscais, contadores e advogados, que são os custos com maior peso no balanço financeiro, já que não possuem obrigações trabalhistas, por exemplo. Algumas EJ entrevistadas estão tendo de utilizar toda a sua receita para cobrir esses custos. Para controlar suas finanças, utilizam um planejamento financeiro anual e com revisões semestrais, as EJ que possuem maiores conhecimentos a respeito dessa ferramenta, trabalham com projeções de cenários. 
Faz parte dos princípios do MEJ que as EJ invistam no desenvolvimento dos seus membros e na sede. Nenhuma das empresas pesquisadas possui um programa formal ou política para reinvestimento. Entretanto, na prática, realizam esse tipo de investimento sempre procurando a capacitação dos seus membros, por meio de cursos técnicos, eventos, palestras e no pagamento de premiações. O investimento também ocorre com a compra de ferramentas, comuns entre as EJ de engenharia.

\section{Relações públicas}

A Concentro é a representante da Brasil Júnior em Brasília e é formada por diretores e membros das EJ federadas. Isso fez com que as empresas juniores se aproximassem mais formando parcerias entre elas.

Para a Conex e a Projetos, a IES tem sido a maior parceira deles, já que os apoiam com materiais, equipamentos e espaço físicos. Nas $\mathrm{EJ}$ da $\mathrm{UnB}$, o relacionamento maior é com o departamento dos cursos. Recentemente, o CDT vem desempenhando um papel de participação com elas, oferecendo eventos, cursos e palestras. Outro exemplo é a AD\&M que tem parcerias mais concretas, além da universidade, com empresas tradicionais do mercado brasileiro, fundações e ONGS.

A Econsult é única EJ que informou ter uma equipe direcionada para a tarefa de captação de clientes, possuindo uma plataforma de gerenciamento da clientela, na qual estipulam prazos e meios para realizar contatos futuros.

Para o canal de comunicação e feedback de clientes, as EJ utilizam questionários e formulários a serem preenchidos pelos clientes durante as entregas das etapas do projeto e/ou no término. Algumas empresas reconhecem que há falhas e que estão se preocupando mais com a comunicação dos seus clientes justamente para continuar o trabalho de pós-venda.

\section{Entrevista com a reitora do Centro Universitário IESB}

O objetivo dessa entrevista era verificar quais fatores que motivaram a IES a abrir uma empresa de consultoria e a percepção diante do projeto. No começo do funcionamento do IESB, ouvia-se muito falar a respeito de empresas juniores, e um grupo de alunos do curso de publicidade tinham o interesse em abrir uma EJ. Então a reitora interessada pelo assunto, jun- 
tou-se com os alunos e foram visitar as EJ de comunicação e publicidade da UnB, com o intuito de conhecer mais a respeito do movimento e ver como os membros se desenvolviam e aprendiam dentro dessas empresas. Após a visita, os alunos tentaram implantar a EJ, mas tiveram constantes dificuldades em se organizarem, deixando o projeto de lado.

O MEJ chamou bastante a atenção da reitora, principalmente pela capacidade que a EJ oferecia para os membros desenvolverem experiências profissionais durante a graduação no curso superior, algo que ficou mais evidente quando um dos seus parentes, que estudava na UnB ingressou em uma das EJ. O assunto passou a chamar bastante a sua atenção e a deixava intrigada pelo fato de o IESB não ter nenhuma iniciativa por parte dos alunos ou até mesmo dos docentes.

Anos depois, um aluno do curso de Administração teve a iniciativa de implantar uma EJ e a reitoria como apoiadora da ideia resolveu alugar um espaço próximo ao campus da faculdade oferecendo toda a reforma, equipamentos e materiais necessários para o funcionamento. A empresa funcionou bem por um tempo, até que o presidente, idealizador do projeto acabou se formando e desligando-se da EJ, passando a presidência a outro membro que, consequentemente não conseguiu dar continuidade ao processo, fazendo com que a EJ encerrasse seu funcionamento tempos depois, tornando mais uma experiência negativa para a IES.

Após esse episódio, passou um tempo sem ninguém tomar iniciativas quanto a um projeto semelhante para o desenvolvimento dos seus alunos. Até que um grupo de alunos do campus da Ceilândia informou que tinha um professor com a intenção em criar um centro de inovação empresarial, que possibilitaria aos alunos terem o contato com práticas de negociações; o projeto chamou a atenção da reitoria e começou a ser desenvolvido até um determinado período, onde, por motivos não expostos, o professor idealizador acabou desligado da IES e o projeto foi interrompido. Entretanto, a reitoria teve o conhecimento de uma professora que estava envolvida inicialmente com o projeto e a chamou para desenvolver outro projeto com os alunos do campus norte, onde começou a idealizar a L2M (2013).

O objetivo inicial por parte da reitoria era desenvolver o projeto para os alunos do curso de Administração e tinha o intuito de possibilitar o desenvolvimento e oferecer experiências práticas. Então resolveu investir, reformando e criando uma estrutura para a sede, oferecendo materiais e recursos para a sua abertura e optou por deixar a coordenadora ter mais autonomia nos processos da empresa. Passado algum tempo da empresa já em funcionamento, 
surgiram conflitos de interesses entre a IES e a L2M, principalmente depois que a coordenadora saiu e indicou um presidente para assumir o seu lugar. Entretanto, o novo coordenador tinha ideias que julgavam inadequadas para a IES e indo totalmente contra os objetivos estipulados no início do projeto, o que acarretou, meses depois no fechamento da empresa. O IESB considera que uma EJ ou um projeto de consultoria é fundamental para desenvolver os seus alunos e retrata toda a infelicidade de ainda não ter conseguido implantar um projeto que de fato desse resultado para os seus discentes.

\section{Questionário dirigido aos alunos do curso de Administração do Centro Universitário IESB}

A terceira etapa do estudo se deu com a aplicação de questionários com os alunos do curso de Administração do IESB, campus norte. O objetivo era verificar os fatores motivacionais e metodologias que os discentes consideram importantes para o seu desenvolvimento profissional durante o período de graduação.

A análise da amostra indicou que cerca de $70 \%$ dos respondentes tinham entre 19 e 24 anos, sendo $56 \%$ do sexo feminino, $40 \%$ realizavam algum estágio e $20 \%$ já atuavam no mercado de trabalho.

Os alunos, em sua quase totalidade (97\%) consideraram que atividades práticas durante a sua graduação no ensino superior tem um peso importante ou muito importante, evidenciando que somente os conteúdos propostos em sala de aula não são considerados suficientes. A Tabela 1 indica as atividades pragmáticas julgadas mais importantes pelos alunos.

Tabela 1- Atividades pragmáticas.

\begin{tabular}{lc}
\hline \multicolumn{2}{c}{ Quais atividades práticas você gostaria que a sua IES oferecesse? } \\
\hline \multicolumn{1}{c}{ Respostas } & $\mathbf{\%}$ \\
\hline Visitas técnicas & $26,9 \%$ \\
Em branco & $24,1 \%$ \\
Cursos e aulas práticas (laboratórios) & $13,9 \%$ \\
Feiras, workshop e palestras & $13,0 \%$ \\
Empresa Júnior & $4,6 \%$ \\
Estudo de caso & $3,7 \%$ \\
Simulação empresarial & $4,6 \%$ \\
Empresa de consultoria & $2,8 \%$ \\
A Instituição já oferece & $1,9 \%$
\end{tabular}




\begin{tabular}{lc}
\hline \multicolumn{2}{c}{ Quais atividades práticas você gostaria que a sua IES oferecesse? } \\
\hline \multicolumn{1}{c}{ Respostas } & $\%$ \\
\hline Estágio obrigatório & $1,9 \%$ \\
Incubadoras & $1,9 \%$ \\
Experiência profissional & $0,9 \%$ \\
\hline
\end{tabular}

Fonte: Elaboração própria.

Por ser uma questão aberta, houve um grande número de respondentes que a deixaram em branco. Do total dos questionários aplicados, $76,1 \%$ responderam a questão e a atividade da qual houve o maior número de repetições foi a visita técnica, seguida por cursos e aulas práticas. No caso, os alunos deram importância mínima à EJ como fonte de experiências pragmáticas, podendo-se inferir que o desconhecimento sobre a existência, a forma de atuação e as possibilidades de inserção nesse tipo de empresa tenha sido o fato predominante na baixa indicação das EJ como desenvolvedora de experiências práticas pelos alunos.

Quanto ao entendimento dos alunos a respeito do que significa uma EJ, verificou-se que apenas 3,7\% julgam conhecer bastante o que vem a ser uma EJ. Por outro lado, diferentemente das EJ, aqui os respondentes que informaram ter um breve conhecimento e conhecerem bastante, somam 58\%, superando um pouco mais da metade dos que informaram saber pouco ou não conhecer atividades de consultoria.

Para complementar o estudo e identificar as técnicas de aprendizados que os respondentes consideram importantes, foi inserida uma questão de escala tipo Likert com algumas metodologias praticadas por docentes e universidades em Brasília.

Tabela 2 - Formas de metodologias e a sua importância.

\begin{tabular}{l|c|c|c|c|c|c}
\cline { 2 - 6 } \multicolumn{1}{c|}{ Metodologias } & NI & PI & ID & IMP & MI & Branco \\
\hline Professores didáticos (utilizam diversas ferramentas) & $0,0 \%$ & $0,9 \%$ & $5,6 \%$ & $24,3 \%$ & $69,2 \%$ & $0,0 \%$ \\
\hline Livros, enciclopédias e apostilas & $0,9 \%$ & $6,5 \%$ & $19,6 \%$ & $43,0 \%$ & $29,9 \%$ & $0,0 \%$ \\
\hline Interatividade na sala de aula & $1,0 \%$ & $2,9 \%$ & $7,7 \%$ & $31,7 \%$ & $55,8 \%$ & $1,0 \%$ \\
\hline $\begin{array}{l}\text { Ambiente/estrutura física da Instituição de Ensino Superi- } \\
\text { or }\end{array}$ & $0,0 \%$ & $1,9 \%$ & $10,4 \%$ & $32,1 \%$ & $55,7 \%$ & $0,0 \%$ \\
\hline Amigos/colegas de sala de aula & $5,7 \%$ & $8,5 \%$ & $20,8 \%$ & $36,8 \%$ & $28,3 \%$ & $0,0 \%$ \\
\hline Ensino a distância & $23,1 \%$ & $25,0 \%$ & $28,8 \%$ & $14,4 \%$ & $8,7 \%$ & $0,0 \%$ \\
\hline Aulas laboratoriais (Práticas) & $2,8 \%$ & $4,7 \%$ & $6,5 \%$ & $34,6 \%$ & $51,4 \%$ & $0,0 \%$ \\
\hline Visitas técnicas & $2,8 \%$ & $5,7 \%$ & $5,7 \%$ & $26,4 \%$ & $59,4 \%$ & $0,0 \%$ \\
\hline Simulações empresariais & $2,8 \%$ & $1,9 \%$ & $7,5 \%$ & $19,8 \%$ & $67,9 \%$ & $0,0 \%$ \\
\hline Feiras, eventos e congressos & $0,0 \%$ & $0,9 \%$ & $11,3 \%$ & $32,1 \%$ & $53,8 \%$ & $1,9 \%$ \\
\hline Parcerias e convênios internacionais (Intercâmbios) & $0,9 \%$ & $0,9 \%$ & $6,6 \%$ & $21,7 \%$ & $69,8 \%$ & $0,0 \%$ \\
\hline
\end{tabular}


Pesquisa sobre empresas juniores em instituições de ensino superior do Distrito Federal: estudo de caso com foco no Centro Universitário IESB

\begin{tabular}{l|c|c|c|c|c|c}
\multicolumn{1}{c|}{ Metodologias } & NI & PI & ID & IMP & MI & Branco \\
\cline { 2 - 7 } $\begin{array}{l}\text { Cursos de extensão (oratórias, profissionalizantes e técni- } \\
\text { cos) }\end{array}$ & $1,0 \%$ & $1,9 \%$ & $11,7 \%$ & $31,1 \%$ & $54,4 \%$ & $0,0 \%$ \\
\hline Empresas Juniores & $1,0 \%$ & $5,8 \%$ & $28,8 \%$ & $34,6 \%$ & $29,8 \%$ & $0,0 \%$ \\
\hline Resoluções de exercícios e estudos de caso & $1,9 \%$ & $3,8 \%$ & $16,0 \%$ & $34,0 \%$ & $44,3 \%$ & $0,0 \%$ \\
\hline
\end{tabular}

Fonte: elaboração própria.

Legenda: (NI) Nada importante, (PI) Pouco importante, (ID) Indiferente, (IMP) Importante, (MI) Muito importante.

Para a maioria dos respondentes, a forma de aprendizado considerada muito importante é a realização de intercâmbios, prática que não foi lembrada na questão aberta. Ainda em comparação com a Tabela 1, a visita técnica que foi a mais lembrada por 26,9\% dos alunos, aparece na Tabela 2 com 85,8\% considerando-a importante e muito importante. Já o ensino a distância foi o item com o maior número de reprovações, chegando a 48,1\% dos respondentes considerando-a nada importante e pouco importante. Para servir de comparação, o segundo item com maior número de reprovações chegou a 14,2\%, uma diferença relativamente alta.

Dentro da sala de aula os alunos também consideram que os professores mais didáticos são muito importantes para o aprendizado, tendo a necessidade de buscar outros meios para passarem as informações aos discentes. As EJ tiveram a maior parte das respostas consideradas importantes chegando a 34,6\%, entretanto, o número de respondentes que a consideraram indiferentes se aproximou bastante do primeiro dado, chegando a $28,8 \%$, sendo o item com maior número de indiferentes, empatado com o ensino a distância.

O último tópico abordado foram os fatores motivacionais para que os alunos participem de projetos oferecidos pela IES. A Tabela 3 apresenta os resultados.

Tabela 3 - Fatores motivacionais.

\begin{tabular}{l|c|c|c|c|c|c}
\cline { 2 - 7 } \multicolumn{1}{c|}{ Fatores } & NM & PM & ID & MOT & MM & Branco \\
\hline Aprendizado técnico & $0,0 \%$ & $1,9 \%$ & $11,3 \%$ & $43,4 \%$ & $41,5 \%$ & $1,9 \%$ \\
\hline Crescimento profissional & $0,0 \%$ & $0,0 \%$ & $4,7 \%$ & $31,8 \%$ & $62,6 \%$ & $0,9 \%$ \\
\hline Experiência profissional & $0,9 \%$ & $0,0 \%$ & $8,4 \%$ & $32,7 \%$ & $57,0 \%$ & $0,9 \%$ \\
\hline Trabalhar na área profissional desejada & $0,0 \%$ & $2,8 \%$ & $10,3 \%$ & $19,6 \%$ & $66,4 \%$ & $0,9 \%$ \\
\hline Contatos profissionais (network) & $0,0 \%$ & $3,8 \%$ & $10,4 \%$ & $34,9 \%$ & $50,9 \%$ & $0,0 \%$ \\
\hline Remuneração fixa & $0,9 \%$ & $7,5 \%$ & $11,2 \%$ & $34,6 \%$ & $44,9 \%$ & $0,9 \%$ \\
\hline Receber por projetos executados & $1,0 \%$ & $4,8 \%$ & $14,3 \%$ & $34,3 \%$ & $44,8 \%$ & $1,0 \%$ \\
\hline Trabalhar voluntariamente & $4,6 \%$ & $10,2 \%$ & $29,6 \%$ & $32,4 \%$ & $21,3 \%$ & $1,9 \%$ \\
\hline Horário a cumprir & $2,8 \%$ & $11,3 \%$ & $27,4 \%$ & $34,0 \%$ & $23,6 \%$ & $0,9 \%$ \\
\hline Bolsas de desconto na faculdade & $0,9 \%$ & $2,8 \%$ & $11,3 \%$ & $32,1 \%$ & $51,9 \%$ & $0,9 \%$ \\
\hline
\end{tabular}




\begin{tabular}{|c|c|c|c|c|c|c|}
\hline Fatores & NM & PM & ID & MOT & MM & Branco \\
\hline Cursos e palestras técnicas. & $1,0 \%$ & $2,9 \%$ & $13,3 \%$ & $39,0 \%$ & $42,9 \%$ & $1,0 \%$ \\
\hline Horas complementares para a faculdade & $1,9 \%$ & $6,5 \%$ & $14,0 \%$ & $29,9 \%$ & $45,8 \%$ & $1,9 \%$ \\
\hline Opção de cumprir estágio supervisionado obrigatório & $3,8 \%$ & $7,6 \%$ & $28,6 \%$ & $24,8 \%$ & $34,3 \%$ & $1,0 \%$ \\
\hline Ambiente de baixa pressão por resultados & $9,2 \%$ & $14,7 \%$ & $27,5 \%$ & $24,8 \%$ & $22,9 \%$ & $0,9 \%$ \\
\hline
\end{tabular}

Fonte: Elaboração própria.

Legenda: (NM) Nada motivador, (PM) Pouco motivador, (ID) Indiferente, (MOT) Motivador, (MM) Muito motivador.

Nessa questão, foi possível avaliar que para os graduandos do curso de Administração, a IES oferecer projetos com oportunidades para trabalhar na área profissional desejada é o fator determinante considerado motivador e muito motivador, chegando juntos a um percentual de $86 \%$ do total. O trabalho voluntário recebeu a maior indicação como fator indiferente para a motivação, chegando a 29,6\% ainda mais se usarmos a remuneração fixa e remuneração por projetos executados como referência e obtendo $44,9 \%$ e $44,8 \%$ respectivamente, das respostas considerando muito motivador.

De acordo com a pesquisa, 5 itens merecem a atenção da IES no momento em que for desenvolver um projeto para os seus alunos, sendo eles: possibilitar ao discente trabalhar na área profissional desejada, crescimento profissional, bolsas de desconto na faculdade, contatos e experiências profissionais, itens que ultrapassaram $50 \%$ das respostas de muito motivador.

\section{Recomendações para criação de empresas de consultoria em IES}

Partindo-se dos estudos realizados, é possível propor algumas recomendações para a criação de empresas juniores, conforme se apresenta a seguir, de forma resumida.

a) Definição do Negócio: espera-se que a IES já tenha o coordenador contratado e que essa etapa seja toda elaborada por ele. A elaboração de um plano de negócio (já envolve as partes acima), definindo a sua atuação, quem será o público-alvo, os seus produtos, mão de obra, infraestrutura, atuação de marketing, assuntos nos quais serão comentados no decorrer do modelo. O planejamento estratégico é importantíssimo e será o documento de parâmetros para avaliar se as ações tomadas estão seguindo o objetivo, assim tanto a empresa, e principalmente a IES terão uma ferramenta de controle.

b) Relacionamento com a IES: relacionamento com a IES é um fator crítico de sucesso, a 
exemplo, foi a L2M que não conseguindo alinhar seus objetivos com os da instituição, acabou tendo suas operações encerradas. A comunicação entre a IES e a empresa deverá ser feita sempre pelo coordenador da empresa, já que foi ele quem definiu o planejamento estratégico junto com a IES.

c) Autonomia dos Gestores: A criação de um conselho na estrutura organizacional da empresa é uma boa solução para a IES acompanhar as tomadas de decisões da empresa. Na autonomia incluem-se as contas bancárias e CNPJ distintos da IES.

d) Infraestrutura: O fato de ter uma IES como investidora é um ponto a favor, já que, em sua maioria, tem condições de oferecer espaços e equipamentos, que normalmente se encontra em ócio. Em todas as empresas entrevistadas nesse estudo, teve o seu espaço físico cedido pala IES na qual são filiadas. As IES particulares tiveram interesse maior na colaboração para as empresas, e além de cederem os espaços, patrocinaram as reformas, equipamentos eletrônicos e móveis.

e) Nome da IES: O nome da faculdade, ou seja, sua representatividade no mercado, associado à empresa de consultoria criada é algo que poderá passar confiança na hora de arrumar parceiros e clientes. A sede da empresa estando dentro da IES aumenta ainda mais esse vínculo. Vale ressaltar, que dependerá de cada instituição e do objetivo traçado.

f) Professores como parceiros: Outro fato comum nas IES são a contratação de professores e coordenadores com experiências de mercado para darem aulas. Esses profissionais, se integrados ao cotidiano da empresa, poderão tornar-se parceiros de peso, principalmente se a empresa ceder espaço para que os professores tragam projetos que possam ser executados em conjunto com a empresa, gerenciar os projetos de consultoria, prestar treinamentos e palestras para os membros - uma vez que a experiência de mercado unida com a didática, tornará mais fácil para o aprendizado dos membros.

g) Relacionamento com os discentes e docentes da IES: Como o objetivo da empresa instalada em IES é a capacitação dos membros, possibilitando aos alunos terem experiências práticas das teorias vistas em sala de aula, o quadro de pessoal da empresa, será composto em sua maioria por alunos da própria IES. Os professores e coordenadores de cursos também são peças importantes para esse relacionamento, uma vez que os próprios professores tendo conhecimento da empresa poderão repassar para os alunos na sala de aula, divulgando e aumentando o conhecimento dos alunos em relação ao 
cotidiano da empresa. Pode-se observar pelo estudo, que a maior parte das EJ não tem essa preocupação, fazendo o contato somente com os alunos calouros de cada semestre, e nos períodos em que divulgam a data do seu processo seletivo. Vale ressaltar que os alunos tendo constante conhecimento e informações a respeito da empresa, poderão despertar neles, interesses que não foram percebidos em momentos anteriores, atingindo assim um maior público de interessados a ingressarem na empresa.

h) Estrutura Organizacional: O organograma base, não fugirá muito do que já foi visto no estudo. Ele dependerá das áreas que a empresa atuará e a sugestão como citada no tópico autonomia dos gestores, é a criação de um conselho, composto por representantes das partes envolvidas, conforme a Figura 3.

Figura 2 - Proposta de organograma.

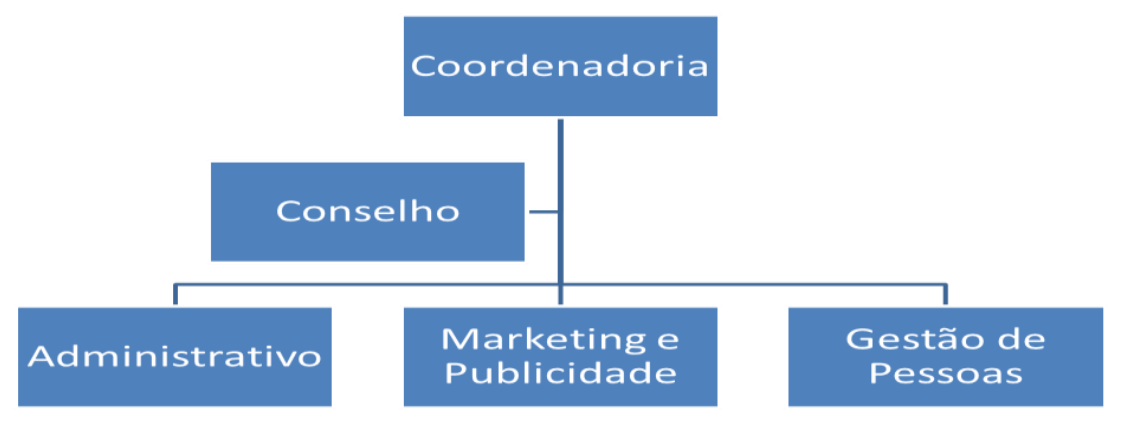

Fonte: Elaboração própria.

i) Diversificação das Áreas: A criação das áreas tem de ser estabelecida de acordo com as condições iniciais da empresa e o que a IES poderá oferecer. Sugere-se ter áreas bases da administração, como administrativo financeiro, marketing e gestão de Pessoas. Essas áreas ajudaram a desenvolver os próprios processos internos até a sua abertura. Posterior à abertura, a criação de áreas como de processos, já que envolve consultoria e a de vendas para captar clientes, é um fator que mostrou dar resultado nas EJ. Com a maturação da empresa, acrescentar núcleos de consultoria que envolvam outros cursos da IES pode ser uma boa estratégia, já que assim, atingirão mais alunos para o desenvolvimento e áreas de atuação para a empresa. Um exemplo seria agrupar todas as EJ da UnB em única empresa, algo que é proposto pela Projetos do UniCEUB. Assim teriam pessoas especializadas em sua área dentro da empresa, ou seja, alunos que fazem 
administração entrando na área administrativa financeira, os que fazem comunicação e publicidade na área de marketing, trazendo alunos que queiram se desenvolver em sua área específica de formação e coordenados por um gerente contratado pela empresa.

j) Gestão de pessoas: Nos processos haverá duas situações distintas entre os membros, sendo elas: fixos e voluntários. Assim, quando mencionado membros fixos, levar em consideração os gerentes e o coordenador da empresa e quando mencionado membros voluntários, serão os alunos. O intuito de ter os funcionários de nível tático e estratégicos fixos é o de preservar os interesses das partes envolvidas e dar sequência ao planejamento estratégico proposto, evitando uma possível rotatividade com o vínculo empregatício. Já os alunos tendo contratos voluntários, conforme realizado pelas EJ, a empresa poderá agregar uma maior quantidade de membros para desenvolvê-los, sem ter um vínculo empregatício e altos custos com folhas salariais.

k) Fontes de recursos: No início, como a empresa ainda não terá uma fonte de receita, aconselha-se trabalhar com baixo custo, o mínimo possível, e que a fonte de receita seja proveniente da faculdade, como ocorreu com a L2M. Por isso é importante o alinhamento entre interesses e objetivos, uma vez que a faculdade tendo investido na empresa, cobrará retornos.

1) Marketing: $O$ marketing é uma ferramenta que se bem trabalhada por uma empresa, se torna um diferencial competitivo entre as suas concorrentes. A empresa de consultoria instalada em uma IES, mesmo que não tenha fins lucrativos, precisa de receitas para manter-se em funcionamento, e que sejam provenientes da execução de projetos e serviços, ou seja, tem a necessidade de captar clientes. Para essas empresas, tanto EJ e a L2M, foram percebidas duas ferramentas de marketing cruciais para o seu sucesso, sendo elas: o marketing de relacionamento e o mix de comunicação e marketing.

\section{Considerações Finais}

O estudo possibilitou verificar meios de gestão para desenvolver uma empresa de consultoria formada por universitários em sua maioria, tornando um ambiente mais propício ao aprendizado e o desenvolvimento dos seus membros, diminuindo a pressão que uma empresa convencional teria por resultados, mas sem perder o nível de profissionalismo. Isso tende a 
aproximar o exercício acadêmico da atividade prática, o que corrobora com os achados de Augusto (2015).

O MEJ desenvolve bem essa intenção, mas pode-se perceber que ainda há muitas brechas para discutir a respeito dos procedimentos e modelos das EJ, como por exemplo, ajudálos em questões administrativas, criar ferramentas de integração entre as EJ do movimento, para que de fato, aproveitem ao máximo a força de cada EJ e o relacionamento com clientes e parceiros.

As amostras utilizadas no estudo permitiram avaliar a percepção de uma empresa de consultoria universitária em diversos ângulos, abordando a visão por meio da IES, EJ e alunos da graduação do ensino superior.

$\mathrm{Na}$ entrevista com as EJ, pôde-se perceber o entusiasmo em relação ao MEJ, como os presidentes enxergam todo o potencial e a diferença que podem causar com o seu trabalho, desenvolvendo o espírito empreendedor e profissional nos seus membros. A questão do empreendedorismo reforça os estudos realizados por Battisti, Vigorena e Knie (2011), ao estudar EJ voltadas exclusivamente para o Secretariado Executivo.

A entrevista com a reitora possibilitou perceber melhor como funcionou uma empresa de consultoria instalada em uma IES, mostrando suas vantagens e desvantagens, oferecendo informações claras para o desenvolvimento da proposta do modelo da empresa, já que a L2M foi a maior referência para o autor desenvolver a proposta. Com a aplicação do questionário para os alunos de administração do IESB norte, as informações também foram úteis no desenvolvimento da proposta, já que foram levantadas questões como fatores que consideram importantes para o seu aprendizado no período de graduação e fatores motivacionais para participarem de projetos oferecidos por uma IES, o que inclui a empresa de consultoria, possibilitando trabalhar com ferramentas para atrair e manter por mais tempo os discentes na empresa.

Para estudos futuros sugere-se verificar: 1) quanto uma empresa de consultoria pode gerar retorno para as IES?; 2) qual o papel que a empresa pode desenvolver, economicamente e socialmente falando a nível local e regional para a população e empresários; 3) quais os fatores levariam os empresários a procurarem e confiarem nas EJ e empresas de consultoria instaladas em IES; 4) até que ponto o nome da faculdade pode influenciar em negociações de novos clientes e parceiros; e, 5) quais os fatores que indicariam ser viável economicamente estabelecer-se uma EJ em uma IES? 


\section{Referências}

AD\&M - Consultoria Empresarial. Sobre a AD\&M (2015). Site institucional. Recuperado em 26 fevereiro, 2018, de: 〈http://www.admconsultoria.com.br/sobre/>. Acesso em: 2 abr. 2015 .

Augusto, M. N. (2015) Contribuições da empresa júnior para uma formação inovadora do discente na graduação em Comunicação. Universidade Municipal de São Caetano do Sul: São Caetano do Sul. Recuperado em 26 fevereiro, 2018, de: <http://repositorio.uscs.edu.br/handle/123456789/713>.

Battisti, P., Vigorena, D. \& Knie, D. (2012). Empresa júnior: um estudo multicaso em cursos de secretariado executivo no Brasil. Revista Expectativa, 10(10), 75-90. Recuperado em 26 fevereiro, 2018, de: <http://erevista.unioeste.br/index.php/expectativa/article/view/6095/4699>.

Brasil Júnior. (2012). Conceito Nacional de Empresa Júnior. Brasília: Confederação Brasileira de Empresas Juniores. Recuperado em 26 fevereiro, 2018, de: <https://www.brasiljunior.org.br/uploads/cms/institutional/file/file/5/CNEJ.pdf>.

. (2012). DNA Júnior. Brasília: Confederação Brasileira de Empresas Juniores. Recuperado em 26 fevereiro, 2018, de: <http://www.fejepar.org.br/arquivos/download/6.pdf $>$.

(2014). Parecer Final Selo EJ 2014. Brasília: Confederação Brasileira de Empresas Juniores. Recuperado em 26 fevereiro, 2018, de: <https://issuu.com/brasiljunior/docs/selo_ej_-_edital_2014>.

Concentro (2015). Lista de contatos. Brasília: Conselho Concentro (documento restrito).

Dias, T. R. F. V.; Vilas Boas, A. A.; Oliveira, G.Z. \& Moreira, L. F. S. (2010). Características comportamentais empreendedoras dos estudantes membros de duas empresas juniores. 
XIII SemeaAD - Seminários em Administração. Recuperado em 26 fevereiro, 2018, de: <http://sistema.semead.com.br/13semead/resultado/trabalhosPDF/932.pdf〉.

L2M (2013). Estudo de viabilidade técnico econômico faixa B. Brasília: Centro Universitário IESB (documento restrito).

L2M (2014). Aprendizado e gestão. Brasília: Centro Universitário IESB, 2014. 36 slides. color. (documento restrito).

Peixoto, M. C. L. (1997). Ensino Superior: desafios e questões atuais. Trabalho e Educação, Belo Horizonte, vol. 2, n .2, pp.171-190, ago./dez. 1997. Recuperado em 26 fevereiro, 2018, de: < https://seer.ufmg.br/index.php/trabedu/article/view/7140>.

Santos, M. G., Brito-de-Jesus K. C., Souza-Silva, J. C., Silva, V. A. \& Franco, A. P. S. (2013). Como aprendem os empresários juniores no Brasil: um estudo quantitativo sobre as modalidades de aprendizagem organizacional. Revista Gestão e Planejamento. vol. 14. a. 3. pp. 372-388. set./dez. 2013. Recuperado em 26 fevereiro, 2018, de: <ttp://www.revistas.unifacs.br/index.php/rgb/article/view/2605/2151>.

Santos, R. A. (2012). Desenvolvimento de competências profissionais em alunos de Engenharia: estudo de empresa júnior como ferramenta de integração teoria - prática. Revista Lugares de Educação, Bananeiras/PB, vol. 2, n. 1, pp. 3-13, jan.-jun. 2012. Recuperado em 26 fevereiro, 2018, de: <http://www.okara.ufpb.br/ojs/index.php/rle/article/view/11945/7770>.

Souza, G. C. (2002). Empresa Júnior, uma ferramenta facilitadora do processo de aprendizagem através da aplicação imediata de conceitos e teorias à realidade empresarial no ensino de administração no Brasil. Revista ANGRAD, Rio de Janeiro: Associação Nacional dos Cursos de Graduação em Administração, vol. 3, n. 4, pp. 98-111, out./dez. 2002. Recuperado em 26 fevereiro, 2018, de: <http://old.angrad.org.br/_resources/_circuits/article/article_1083.pdf>. 